\title{
A COMPARATIVE STUDY OF TLR7 EXPRESSION IN DIFFERENT HISTOLOGICAL GRADES OF ORAL SQUAMOUS CELL CARCINOMA (An Immunohistochemical Study)
}

\author{
Nermine G. El-Bahey ${ }^{1} M S c$, Taissir A. Omar ${ }^{2} P h D$, Hamed A. Fouad ${ }^{2}$ PhD, Sahar M. El- \\ Sheikh$^{2} P h D$, Radwa A. Mehanna ${ }^{3} P h D$, Marwa M. Afifi ${ }^{4} P h D$.
}

\begin{abstract} (LSAB). tumor, with a higher expression noted in the more differentiated tumors.

CONCLUSIONS: The expression of TLR7 in OSCC may be used as a prognostic marker.

KEYWORDS: Oral squamous cell carcinoma, Toll-like receptor 7, immunohistochemistry.

1. Assistant lecturer in Oral Pathology Department, Faculty of Dentistry, Pharos University.

2. Professor in Oral Pathology Department, Faculty of Dentistry, Alexandria University.

3. Assistant Professor in Physiology Department, Faculty of Medicine, Alexandria University.

4. Lecturer in Oral Pathology Department, Faculty of Dentistry, Alexandria University.
\end{abstract}

INTRODUCTION: Oral squamous cell carcinoma (OSCC) accounts for the sixth most prevalent malignant neoplasm worldwide, representing $90 \%$ of all oral cancers. Despite advances in the detection and treatment, the unsatisfactory prognosis for OSCC has remained stable for decades. To date, cancer research is focused on improving cancer treatment methods using immunotherapy. The Toll-like receptors family (TLR) has served that purpose. These are a family of pattern recognition receptors (PRRs) that represent essential components of the host's immune responses. The expression of some TLRs, including TLR7, in different tumors has been confirmed in various studies. The clarification of the TLR7 expression and role in OSCC may thus provide new strategies and prospects for more effective cancer diagnosis and treatment. OBJECTIVES: To evaluate the expression of TLR7 in human OSCC and correlate it with the different histopathological grades of the tumor. MATERIALS AND METHODS: The TLR7 expression was examined in 10 normal mucosal and 30 OSCC tissue samples. The immunohistochemical (IHC) staining with the anti-TLR7 antibody was performed using the Labeled Strept-Avidin Biotin complex method

RESULTS: TLR7 was expressed in all OSCC cases and showed significant difference in its expression among the different grades of the

Corresponding author

E-mail: nermine.elbahey@gmail.com

\section{INTRODUCTION}

Oral cancer (OC), a subtype of head and neck cancer, is a major public health concern and is one of the top 10 most commonly occurring cancers worldwide. Oral squamous cell carcinoma (OSCC) accounts for more than $90 \%$ of all OC cases, and is more prevalent in the developing countries. It represents the 6th most common cancer worldwide, and the 4th ranked cancer in the Eastern Mediterranean region (1-3). Despite advances in the diagnosis and treatment modalities, the 5-year survival rate for OSCC has remained largely unchanged for decades. The etiology of the disease is multifactorial. It is known that chronic inflammation is one of the predisposing factors to cancer development and progression $(4,5)$.

In this context, the Toll-like Receptors (TLRs) are emerging as the key players in eliciting the host's inflammatory responses, where they support the homeostasis. These are one of the pattern recognition receptors (PRRs), which detect the exogenous stimuli of harmful invading pathogens or endogenous danger from injured or dead cells through pathogen- or damageassociated molecular patterns (PAMPs/ DAMPs), respectively. Nearly thirteen TLRs have been identified in mammals so far, of which ten have been reported in humans (TLR1-10) (6,7). Although TLRs are mainly expressed by both the innate and adaptive immune cells, their expression is also observed in a plethora of non-immune cells, especially those that constitute the physical barriers, such as the non-malignant keratinocytes, fibroblasts, as well as in malignant epithelial cells $(8,9)$.

Although TLRs have been extensively studied for their central role in the immune responses against microbial infection, plenty of studies have uncovered their controversial role in tumor biology. The TLR signaling can either dampen the anti-tumor functions of the immune cells in a way that promotes cancer progression, or may enhance the tumor suppression by inducing an immune activation $(10,11)$. Several reports suggested the involvement of TLRs in different cancers, including those of the head and neck, where they showed complex and contradictive roles. Since the oral cavity harbors many microbes, the oral epithelial cells also express functional TLRs, which may play an important role in OC. Yet, studies related to the association of different TLRs in the progression of various grades of OSCC are very limited $(12,13)$.

TLR7, a receptor that recognizes viral single-stranded RNA, is located in the endosomal compartments of plasmacytoid dendritic cells (pDCs), B lymphocytes, natural killer cells, and virally infected cells (14). It has also been reported to be expressed by a variety of cancer cells. 
TLR7 shows a versatile behavior in the tumor microenvironment with either protumorigenic or antineoplastic effects. In various cancers, TLR7 has been suggested to have either a prognostic role in in vivo studies, or a functional role in in vitro studies (15-18). However, the distinct expression and function of TLR7 in head and neck tumors, especially OSCC, are unclear.

To the best of our knowledge, no reports in the English literature are available for the association of TLR7 expression with OSCC in the Egyptian population. This study was thus conducted to examine and compare the IHC expression of TLR7 in the different histopathological grades of OSCC.

\section{MATERIALS AND METHODS \\ Study material}

The current study was performed in the Faculty of Dentistry, Alexandria University after gaining the approval of the Research Ethics Committee. Biopsy samples from the primary oral tumors $(n=30)$ were collected from the patients during the standard surgical procedures. All patients were operated on in the CranioMaxillofacial and Plastic Surgery Department. The control group included specimens of the normal oral tissue $(n=10)$, which were obtained from patients during surgical removal of non-tumor treatment such as the removal of asymptomatic third molars. The biopsies of the patients and the bio-archiving were in compliance with the Code of Professional Ethics for Dentistry adopted by the Alexandria University, Faculty of Dentistry.

\section{Histopathological and immunohistochemical analysis}

The specimens were fixed in $10 \%$ neutral buffered formalin, processed and embedded in paraffin wax using the conventional procedures. Three serial sections of each tissue block were then sliced into 3-4 $\mu \mathrm{m}$ thickness and coded numerically with no other identifying features placed on the slides. One section was stained with the routine hematoxylin and eosin (H\&E) to confirm the diagnosis of the tumor grading by at least two experienced pathologists in the Oral Pathology Department at the Faculty of Dentistry, Alexandria University.

The other two sections were stained immunohistochemically using the Labeled Strept- Avidin Biotin complex method(LSAB) (19). The primary polyclonal rabbit anti-human TLR 7 antibody (ab45371; Abcam, USA) was applied to the slides using the optimal concentration for the immunostaining as recommended by the supplier and incubated for $2 \mathrm{~h}$ at $37^{\circ} \mathrm{C}$. All sections were then examined and analyzed using a light microscope with an attached digital camera. The intensity of the immunostaining was quantified in terms of both the mean area percent (AP) and the mean optical density (OD) by the computer image analyzer software (NIH, USA).

\section{Statistical analysis}

Statistical package for social sciences version 20.0 (SPSS 20.0, SPSS Inc., Chicago, IL, USA) was carried out for the statistical analyses and calculations of data (20). The differences in the mean OD and AP in OSCC cases were calculated using the oneway repeated measures analysis of variance (ANOVA) and the Post Hoc (Tukey) tests. Any P-values equal to or less than 0.05 were considered statistically significant. All the data are expressed as mean \pm SD (standard deviation).

\section{RESULTS}

\section{Clinical Results}

The current study included 30 patients with OSCC. The mean age of the patients was 57.9 years $( \pm 9.13)$, where the youngest patient was 42 and the oldest one was 72 years old at the time of surgery. The gender distribution was 16 (53.3\%) and 14 (46.7\%) for males and females, respectively. The majority of the cases were located on the lateral side of the tongue (70\%), whereas the labial mucosa was the least site of occurrence (3\%).

\section{Histopathological Results}

Based on the microscopical examination, the total 40 samples included in this study were classified into ten cases of normal oral mucosa (NOM), and 30 cases of the various histological grades of OSCC, of which $33.3 \%(n=10)$ were well differentiated, $53.4 \% \quad(n=16)$ were moderately differentiated, and $13.3 \%(n=4)$ were poorly differentiated.

\section{Immunohistochemical Results}

The IHC staining of all NOM and OSCC samples was performed using the anti-TLR7 antibody. It showed that TLR7 was expressed in all (100\%) the assessed samples, localized in the cytoplasm, nucleus and nuclear membrane, yet with varying intensities.

The $\mathbf{N O M}$ cases were positive for the anti-TLR7 antibody. To analyze the results, the surface epithelia were divided into three regions: lower (basal), middle (spinous), and upper (superficial). The majority of the samples showed a weak diffuse cytoplasmic staining along the same particular region of the epithelium. The common finding in all the NOM samples was that the TLR7 expressing cells were most frequently notable in the basal and parabasal cell layers, where the expression tapered off towards the more superficial epithelial layers (Figure 1).

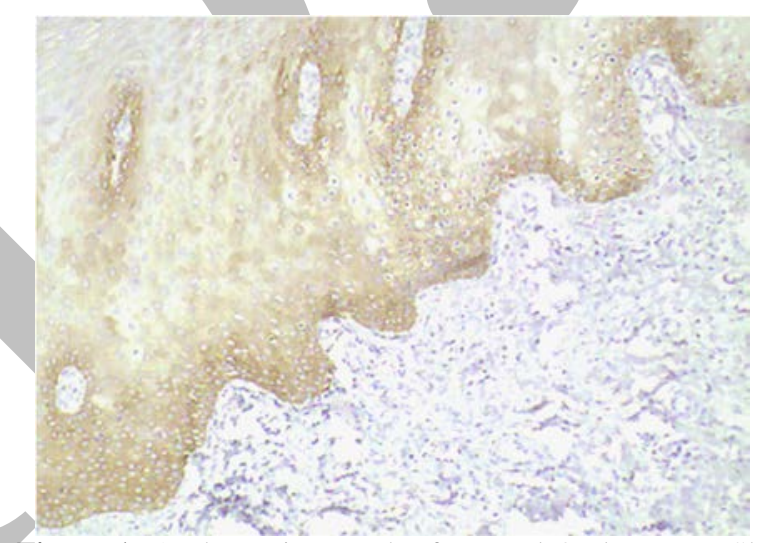

Figure 1: A Photomicrograph of Normal Oral Mucosa Showing Positive TLR7 Immunostaining in the Basal and Parabasal Cell layers. (x100).

All the studied three categories of OSCC cases showed a notable variable positive TLR7 expression, both in terms of the intensity and distribution of the positive epithelial cells.

The well differentiated OSCC (WDSCC) cells showed diffuse, but relatively strong, positive cytoplasmic immunosignals of TLR7 in the malignant epithelial cells, as well as in the keratin pearls (Figure 2). 


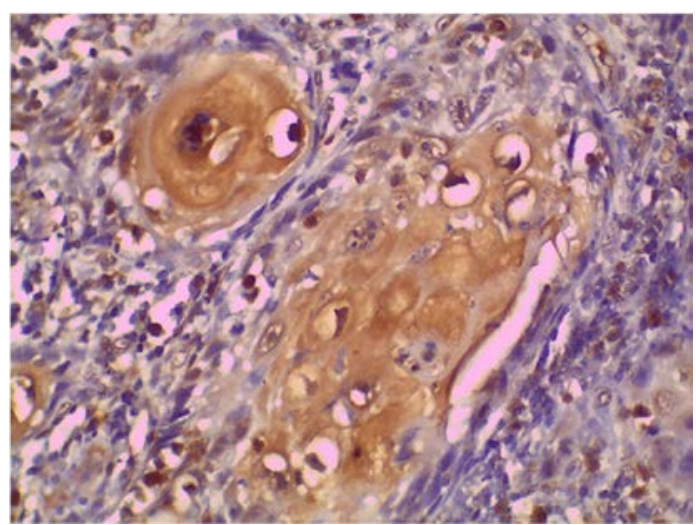

Figure 2: A Photomicrograph of a Well Differentiated Squamous Cell Carcinoma Showing a Strong Positive Cytoplasmic TLR7 Immunoexpression in the Malignant cells. (x400).

In all the moderately differentiated OSCC (MDSCC) cases, the cells showed a strong positive TLR7 staining intensity, which was clearly detectable in the invasive squamous cells present in the stroma. The pattern of TLR7 expression was mainly cytoplasmic, with some nuclear and nuclear membranous expression (Figure 3).
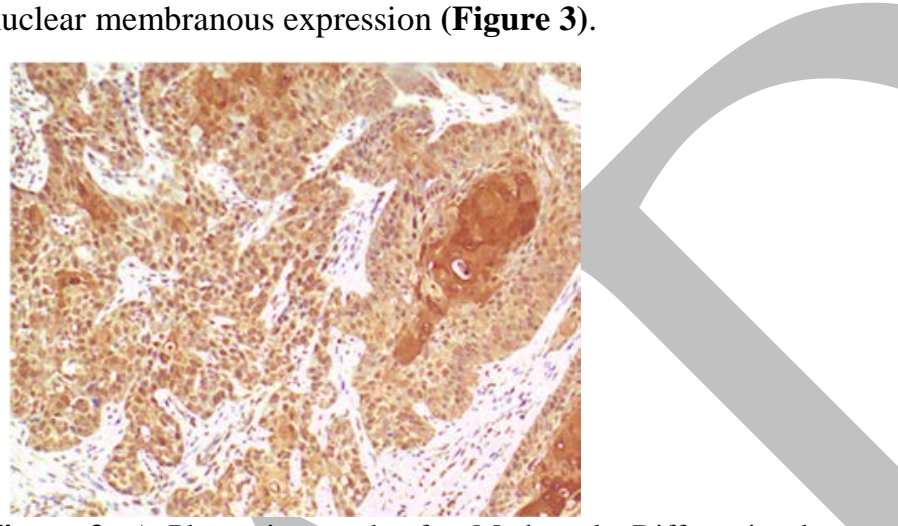

Figure 3: A Photomicrograph of a Moderately Differentiated Squamous Cell Carcinoma Showing Strong Positive Cytoplasmic and Nuclear Immunoreactivity to TLR7 in the Malignant cells. (x400).

In the poorly differentiated OSCC (PDSCC), there was a positive faint to moderate cytoplasmic and nuclear membranous immunostaining in the highly anaplastic malignant epithelial cells. Abnormal mitotic figures as well as apoptotic bodies could be detected (Figure 4).

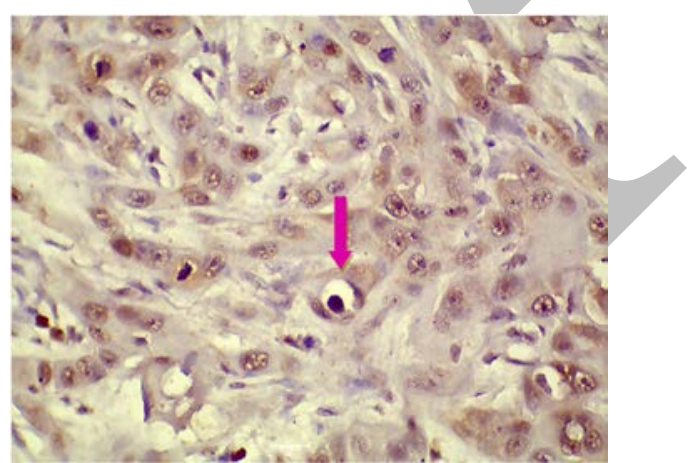

Figure 4: A Photomicrograph of a Poorly Differentiated Squamous Cell Carcinoma Exhibiting Weak to Moderate Cytoplasmic TLR7 Immunosignals. Nuclear TLR7 Expression is Scarce or Absent. Note the Apoptotic cell (Arrow). (x400).

\section{Correlation of TLR7 expression with the different histological grades of OSCC}

The different TLR7 immunoexpression was compared between all the assessed OSCC samples in terms of the mean $A P$ and mean $O D$. The statistical analysis confirmed that the TLR7 expression was higher in all the OSCC cases as compared to the NOM. The WDSCC and MDSCC cases expressed the highest amount of TLR7, while the PDSCC cases showed the least expression. The difference of TLR7 immunostaining among the three grades was statistically significant. The MDSCC cases revealed the highest mean values for both the $\boldsymbol{A P}(74.98 \pm 4.23)$ as well as the $\boldsymbol{O D}$ (70.38 \pm 6.26$)$. The least mean values for both the $\boldsymbol{A P}$ as well as the $\boldsymbol{O D}$ were detected in the cases of PDSCC, being (45.4 \pm 2.28$)$ and (28.68 \pm 6.01$)$, respectively. The Post Hoc (Tukey) Test showed consistently statistically significant differences in the mean values of the $\boldsymbol{A P}$ and $\boldsymbol{O D}$ between all the study samples at a $P$ value $\leq 0.05$. The results are summarized in Tables $\mathbf{1}$ and $\mathbf{2}$.

Table (1): Comparison between the TLR 7 Receptor Immunoexpression in the Different Histological Grades of OSCC According to the Mean of the Area Percent

\begin{tabular}{|c|c|c|c|c|c|c|}
\hline $\begin{array}{c}\text { Mean of } \\
\text { area } \\
\text { percent }\end{array}$ & $\begin{array}{c}\text { Normal } \\
\text { Oral } \\
\text { Mucosa }\end{array}$ & $\begin{array}{c}\text { Well } \\
\text { differenti } \\
\text { ated } \\
\text { OSCC }\end{array}$ & $\begin{array}{c}\text { Moderat } \\
\text { e } \\
\text { differenti } \\
\text { ated } \\
\text { OSCC }\end{array}$ & $\begin{array}{c}\text { Poorly } \\
\text { different } \\
\text { iated } \\
\text { OSCC }\end{array}$ & $\mathbf{F}$ & $\mathbf{P}$ \\
\hline $\begin{array}{l}\text { Min. - } \\
\text { Max. }\end{array}$ & $\begin{array}{c}22.81- \\
29.30\end{array}$ & $\begin{array}{c}60.14- \\
78.73\end{array}$ & $\begin{array}{c}65.72- \\
79.08\end{array}$ & $\begin{array}{l}42.2- \\
47.67\end{array}$ & & \\
\hline $\begin{array}{l}\text { Mean } \\
\pm \text { SD. }\end{array}$ & $\begin{array}{c}25.15 \pm \\
2.602\end{array}$ & $\begin{array}{c}67.54 \pm \\
5.99\end{array}$ & $\begin{array}{c}74.98 \pm \\
4.23\end{array}$ & $\begin{array}{c}45.4 \pm \\
2.28\end{array}$ & 309.6 & $\begin{array}{l}<0.0 \\
01^{*}\end{array}$ \\
\hline $\begin{array}{l}\text { Media } \\
\text { n }\end{array}$ & 24.15 & 66.56 & 76.31 & 45.9 & & \\
\hline $\begin{array}{l}\text { Sig. bet. } \\
\text { grps. }\end{array}$ & \multicolumn{4}{|c|}{$\mathrm{p}_{1}=0.003^{*}, \mathrm{p}_{2}<0.001^{*}$} & & \\
\hline
\end{tabular}

F: F value for ANOVA test, pairwise comparison bet. each 2 groups were done using Post Hoc Test (Tukey)

$\mathrm{p}$ : $\mathrm{p}$ value for comparing between the different groups

$\mathrm{p}_{1}$ : $\mathrm{p}$ value for comparing between well differentiated SCC and moderately differentiated SCC

p2: $p$ value for comparing between all other groups

*: Statistically significant at $\mathrm{p} \leq 0.05$ 
Table (2): Comparison between the TLR 7 Receptor Immunoexpression in the Different Histological Grades of OSCC According to the Mean of the Optical Density

\begin{tabular}{|c|c|c|c|c|c|c|}
\hline $\begin{array}{l}\text { Mean of } \\
\text { area } \\
\text { percent }\end{array}$ & $\begin{array}{c}\text { Normal } \\
\text { Oral } \\
\text { Mucosa }\end{array}$ & $\begin{array}{c}\text { Well } \\
\text { differenti } \\
\text { ated } \\
\text { OSCC }\end{array}$ & $\begin{array}{c}\text { Moderat } \\
\text { e } \\
\text { different } \\
\text { iated } \\
\text { OSCC }\end{array}$ & $\begin{array}{c}\text { Poorly } \\
\text { different } \\
\text { iated } \\
\text { OSCC }\end{array}$ & $\mathbf{F}$ & $\mathbf{P}$ \\
\hline $\begin{array}{l}\text { Min. - } \\
\text { Max. }\end{array}$ & $\begin{array}{c}18.87- \\
27.54\end{array}$ & $\begin{array}{l}43.7- \\
63.02\end{array}$ & $\begin{array}{c}63.47- \\
78.4\end{array}$ & $\begin{array}{c}19.8- \\
34.6\end{array}$ & & \\
\hline $\begin{array}{l}\text { Mean } \\
\pm \text { SD. }\end{array}$ & $\begin{array}{c}22.55 \pm \\
2.43\end{array}$ & $\begin{array}{c}49.6 \pm \\
5.98\end{array}$ & $\begin{array}{c}70.38 \pm \\
6.26\end{array}$ & $\begin{array}{c}28.68 \pm \\
6.01\end{array}$ & $\begin{array}{c}161 . \\
56^{*}\end{array}$ & $\begin{array}{l}<0.0 \\
01^{*}\end{array}$ \\
\hline $\begin{array}{l}\text { Media } \\
\text { n }\end{array}$ & 22.29 & 48.13 & 70.67 & 31.11 & & \\
\hline $\begin{array}{l}\text { Sig. bet. } \\
\text { grps. }\end{array}$ & \multicolumn{4}{|c|}{$\mathrm{p}_{1}=0.005^{*}, \mathrm{p}_{2}<0.001^{*}$} & & \\
\hline
\end{tabular}

F: F value for ANOVA test, pairwise comparison bet. each 2 groups were done using Post Hoc Test (Tukey)

$\mathrm{p}$ : $\mathrm{p}$ value for comparing between the different groups

p1: $p$ value for comparing between normal oral mucosa and poorly differentiated SCC

$\mathrm{p}_{2}$ : $\mathrm{p}$ value for comparing between all other groups

*: Statistically significant at $\mathrm{p} \leq 0.05$

\section{DISCUSSION}

TLRs are important components of the immune responses in the skin and mucosal tissues, and their altered or deregulated expression has been shown to affect the behavior of several tumors. The role of TLRs in cancer is controversial, as an increased expression and activation of these proteins may result in pro- or antitumorigenic effects depending on the context (6,21-23).

The present work clearly demonstrated a positive TLR7 expression in all the studied samples of the NOM, even though with no strong intensity. In this respect, our findings confirm and extend those reported by several authors, who described that the healthy epithelia, including oral tissues, express an almost full palette of functional TLRs $(8,24-28)$. Since plenty of microflora and pathogenic bacteria exist in the different body epithelia, such as the oral, respiratory, and intestinal epithelial cells, they are therefore logically equipped with a cocktail of PRRs, particularly TLRs, even in the absence of stimulation by PAMPs or DAMPs $(29,30)$.

In accordance with several reports in the literature, the current work revealed that in all sections of the NOM, the cells in the basal layer were more strongly labeled, where the TLR7 staining became gradually weaker towards the spinous and the stratum cornea. This higher content of TLRs in the basal layers may indicate the possibility that TLRs are first and mostly synthesized in the deeply located basal cells and that, while being transported upwards along the epithelial shedding cycle, their synthesis becomes diminished for a variety of reasons $(25,30,31)$.

As for the OSCC sections, the results of the current work revealed a significantly higher TLR7 expression as compared to that of the healthy tissues. Since OSCC is a state of pathology, the immune system has already been evoked and activated as a result, which may explain the higher expression of TLRs to protect the already-diseased underlying tissue. TLR7 exhibits an endosomal location, which is in parallel with its ability to recognize the singlestranded RNA. It may be suggested that in OSCC, the oral tissue becomes more vulnerable to infections and thus becomes a target for the attack by the continuous bathing of oral microflora, which in turn may keep on stimulating a persistent TLR7 expression (14).

The results of the present work were in agreement with those of other studies. For instance, Park et al (32) reported the positive, yet variable, expression of various TLRs in OSCC cell lines and on tissue sections. TLR7 was among those TLRs that were strongly expressed. Moreover, Helminen et al (26) found a positive TLR7 expression in the esophageal adenocarcinoma, which was significantly increased as compared with its normal tissue counterpart.

The IHC staining for TLR7 was mainly cytoplasmic, and occasionally nuclear or nuclear membranous. This is consistent with the results of other studies, which also demonstrated the same expression pattern of TLR7 staining in normal or cancerous cells of different tissues. This finding suggests that it is somewhat likely that different TLRs may translocate to the nucleus. However, the role and function of nuclear translocation of TLRs remain speculative $(27,33)$.

The oncological significance of TLRs seems controversial. The current work revealed a positive TLR7 staining in all the cases of WDSCC, MDSCC and PDSCC, with a significantly higher expression in the MDSCC followed by the WDSCC cases and a significantly lower expression in the PDSCC cases. Similar findings were independently postulated by Kotrashetti et al (31) and Zujun et al (34) during their study on different TLRs expressions (TLR4 and 9) in different grades of oral epithelial dysplasia and OSCC. Although some of their examined PDSCC cases were negative for the TLR immunostaining, they also documented a high TLR intensity staining in the WDSCC and MDSCC, and a low intensity in PDSCC. In contrast, Takala et al. (35) observed an increased TLR expression with an advancing tumor grade. Similarly, Ni et al (36) also revealed that the TLR7 expression was upregulated from the normal epithelium to dysplasia to OSCC, and that the high expression of TLR7 in tumor cells correlated to a poor tumor differentiation for OSCC patients. Moreover, Sheyhidin et al. (37) showed that the TLR7 expression was associated with a worse histological grade in esophageal squamous cell carcinoma.

Noteworthy, the limited information available on the genetic and biological heterogeneity of OSCC has hampered the diagnosis and development of new therapeutic strategies. Considering the obvious versatility of the TLR expression by different tumor cells, two aspects are to be considered. On one hand, the upregulation of the TLR signaling could actively serve the tumor's agenda, owing to its anti-apoptotic activity and promoting tumor progression. On the other hand, components of the TLR system may alternatively enhance the host's immunity in the defense against the transforming malignant cells. Thus, activation of TLRs is considered a double-edged sword, and their role in OSCC remains elusive $(11,21,23,38)$. A new shift is thus directed in pursuing TLR modulators (agonists or antagonists) in the anti-cancer immune research (39). 


\section{CONCLUSION}

The methodology used in the current study, measuring the immunohistochemical expression of TLR7 in OSCC and correlating it with its various histological grades, should raise new questions on the pathobiological basis for this receptor. So, it can be concluded that TLR7 may have a role in the OSCC tumor biology and can be thus used as a potentially useful prognostic indicator.

\section{CONFLICT OF INTEREST}

The authors declare that they have no conflicts of interest.

\section{REFERENCES}

1. Siegel R, Ma JM, Zou ZH, Jemal A. Cancer statistics. 2014. Ca Cancer J Clin. 2014;64:9-29.

2. Rivera C. Essentials of oral cancer. Int J Clin Exp Pathol. 2015;8:11884-94.

3. Kujan O, Farah C, Johnson N. Oral and oropharyngeal cancer in the Middle East and North Africa: Incidence, mortality, trends, and gaps in public databases as presented to the Global Oral Cancer Forum. Transl Res Oral Oncol. 2017;2.

4. Ali J, Sabiha B, Jan HU, Haider SA, Khan AA, Ali SS. Genetic etiology of oral cancer. Oral Oncol. 2017;70:23-8.

5. Smitha T, Mohan CV, Hemavathy S. Clinicopathological features of oral squamous cell carcinoma: A hospital-based retrospective study. J NTR Univ Health Sci. 2017;6:29-34.

6. Kawai T, Akira S. The role of pattern-recognition receptors in innate immunity: Update on toll-like receptors. Nat immunol. 2010;11;373-84.

7. Vidya MK, Kumar VG, Sejian V, Bagath M, Krishnan G, Bhatta R. Toll-like receptors: Significance, ligands, signaling pathways, and functions in mammals. Internat Rev Immunol. 2018;37:20-36.

8. McClure R, Massari P. TLR-dependent human mucosal epithelial cell responses to microbial pathogens. Front Immunol. 2014;5:386.

9. Voogdt C, Van Putten J. Chapter 13: The Evolution of the Toll-Like Receptor System. In: The Evolution of the Immune System. Elsevier Inc: Academic Press, Italy. 2016;p.311-30.

10. Pradere JP, Dapito DH, Schwabe RF. The yin and yang of toll-like receptors in cancer. Oncogene. 2014;33:3485-95.

11. Rich AM, Hussaini HM, Parachuru VPB, Seymour GJ. Toll-like receptors and cancer, particularly oral squamous cell carcinoma. Front Immunol. 2014;5:464.

12. Rydberg C, Månsson A, Uddman R, Riesbeck K, Cardell L-O. Toll-like receptor agonists induce inflammation and cell death in a model of head and neck squamous cell carcinomas. Immunol. 2009;128:600-11.

13. Pakdel F, Pouralibaba F, Pakdel S, Khiyavi RK, Falsafi P, Eslami H, et al. Expression of toll-like receptors in squamous cell carcinoma of the tongue. Arch Appl Sci Res. 2015;7:20-4.

14. Heil F, Hemmi H, Hochrein H, Ampenberger F, Kirschning C, Akira S, et al. Species-specific recognition of single-stranded RNA via toll-like receptor 7 and 8 . Science. 2004;303:1526-9.

15. Ahn MY, Kwon SM, Cheong HH, Park JH, Lee J, Min SK, et al. Toll-like receptor 7 agonist, imiquimod, inhibits oral squamous carcinoma cells through apoptosis and necrosis. J Oral Pathol Med. 2012;41:540-6.

16. Dewan MZ, Vanpouille-Box C, Kawashima N, DiNapoli S, Babb JS, Formenti SC, et al. Synergy of topical toll-like receptor 7 agonist with radiation and low-dose cyclophosphamide in a mouse model of cutaneous breast cancer. Clin Cancer Res. 2012;18:6668-78.

17. Dajon M, Iribarren K, Cremer I. Dual roles of TLR7 in the lung cancer microenvironment. OncoImmunol. 2015;4:e991615.

18. Grimmig $\mathrm{T}$, Matthes $\mathrm{N}$, Hoeland $\mathrm{K}$, Tripathi $\mathrm{S}$, Chandraker A, Grimm $M$, et al. TLR7 and TLR8expression increases tumor cell proliferation and promotes chemoresistance in human pancreatic cancer. Int J Oncol. 2015;47:857-66.

19. Syrbu SI, Cohen MB. An enhanced antigen-retrieval protocol for immunohistochemical staining of formalinfixed, paraffin-embedded tissues. Methods Mol Biol. 2011;717:101-10.

20. Kirkpatrick LA, Feeney BC. A simple guide to IBM SPSS statistics for version 20.0. Student ed. Belmont, Calif.: Wadsworth, Cengage Learning; 2013.

21. Ridnour LA, Cheng RY, Switzer CH, Heinecke JL, Ambs S, Glynn S, et al. Molecular pathways: toll-like receptors in the tumor microenvironment - poor prognosis or new therapeutic opportunity. Clin Cancer Res. 2013;19:13406.

22. Burns EM, Yusuf N. Toll-like receptors and skin cancer. Front Immunol. 2014;5:135.

23. Dajon M, Iribarren K, Cremer I. Toll-like receptor stimulation in cancer: a pro- and anti-tumor doubleedged sword. Immunobiol. 2017;222:89-100.

24. Sugawara Y, Uehara A, Fujimoto Y, Kusumoto S, Fukase K, Shibata K, et al. Toll-like receptors, NOD1, and NOD2 in oral epithelial cells. J Dent Res. 2006;85:5249.

25. Beklen A, Hukkanen M, Richardson R, Konttinen YT. Immunohistochemical localization of Toll-like receptors 1-10 in periodontitis. Oral Microbiol Immunol. 2008;23:425-31.

26. Helminen O, Huhta H, Lehenkari PP, Saarnio J, Karttunen TJ, Kauppila JH. Nucleic acid-sensing tolllike receptors 3,7 and 8 in esophageal epithelium, barrett's esophagus, dysplasia and adenocarcinoma. Oncoimmunol. 2016;5:e1127495.

27. Huhta H, Helminen O, Kauppila JH, Salo T, Porvari K, Saarnio J, et al. The Expression of Toll-like Receptors in Normal Human and Murine Gastrointestinal Organs and the Effect of Microbiome and Cancer. J Histochem Cytochem. 2016;64:470-82.

28. Mäkinen LK, Ahmed A, Hagstrom J, Lehtonen S, Makitie AA, Salo T, et al. Toll-like receptors 2, 4, and 9 in primary, metastasized, and recurrent oral tongue squamous cell carcinomas. J Oral Pathol Med. 2016;45:338-45.

29. Mahanonda R, Pichyangkul S. Toll-like receptors and their role in periodontal health and disease. Periodontol 2000. 2007;43:41-55.

30. Ali A, Natah S, Konttinen Y. Differential expression of Toll-like receptors in chronic hyperplastic candidosis. Oral Microbiol Immunol. 2008;23:299-307.

31. Kotrashetti VS, Nayak R, Bhat K, Hosmani J, Somannavar P. Immunohistochemical expression of TLR4 and TLR9 in various grades of oral epithelial dysplasia and squamous cell carcinoma, and their roles in tumor progression: a pilot study. Biotech Histochem. 2013;88:311-22. 
32. Park J-H, Yoon H-E, Jeon D-I, Ahn S-G, Yoon J-H. Activation of TLR2 and TLR5 did not affect tumor progression of an oral squamous cell carcinoma, YD10B cells. J Oral Pathol Med. 2010;39:781-5.

33. Mäkinen L, Atula T, Häyry V, Jouhi L, Datta N, Lehtonen S, et al. Predictive role of toll-like receptors 2, 4 , and 9 in oral tongue squamous cell carcinoma. Oral Oncol. 2015;51:96-102.

34. Zujun S , Qingqiong L , Dongxia Y , Wantao C , Fuxiarng C. Role of toll-like recep 4 on the immune escape of human OSCC and resistance of cisptatin induced apoptosis . Mol Can. 2012;11:33-6.

35. Takala H, Kauppila JH, Soini Y, Selamder KS, Lehenkari PP, Saamio J, et al. Toll-like receptor 9 is a novel biomarker for esophageal squamous cell dysplasia and squamous cell carcinoma progression. J Innate Immun. 2011;3:631-8.

36. Ni YH, Ding L, Zhang DY, Hou YY, Huang X, Hu Q. Distinct expression patterns of Toll-like receptor 7 in tumour cells and fibroblast-like cells in oral squamous cell carcinoma. Histopathol. 2015;67:730-9.

37. Sheyhidin I, Nabi G, Hasim A, Zhang RP, Ainiwaer J, Ma H, et al. Overexpression of TLR3, TLR4, TLR7 and TLR9 in esophageal squamous cell carcinoma. World J Gastroenterol. 2011;17:3745-51.

38. Huang B , Zhao J , Unkeless JC, Feng ZH , Xiong H. TLR signaling by tumor and immune cells: a double edged sword . Oncogene. 2008;27:218-24.

39. Connolly DJ, O’Neill LA. New developments in Tolllike receptor targeted therapeutics. Curr Opin Pharmacol. 2012;12:510-8.

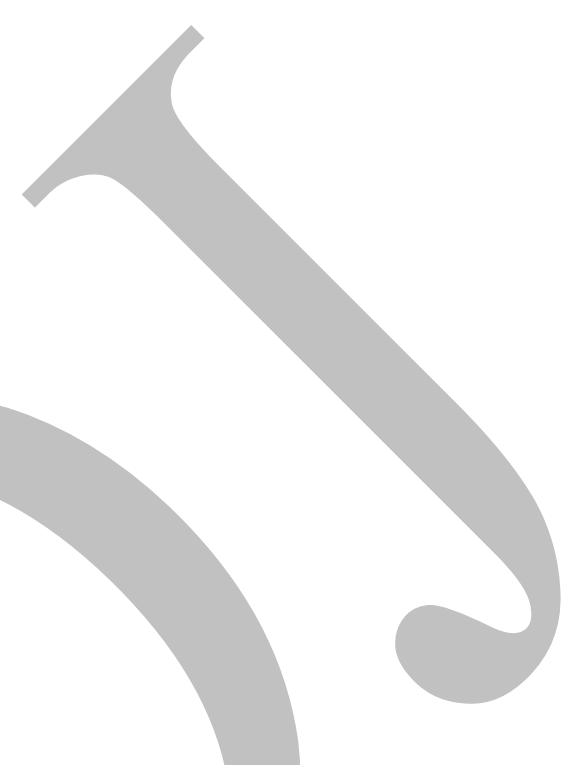

